\title{
Occurrence and Distribution of Entomopathogenic Nematodes in Horticultural Crops Soils of Solan and Sirmaur District of Himachal Pradesh, India
}

\author{
Indra Kumar Kasi ${ }^{1 *}$, Mohinder Singh ${ }^{1}$, Kanchhi Maya Waiba ${ }^{2}$ and Monika ${ }^{1}$ \\ ${ }^{1}$ Department of Entomology, Dr. Yashwant Singh Parmar University of Horticulture and Forestry, Himachal Pradesh, India \\ ${ }^{2}$ Department of Vegetable Science and Floriculture, CSK Himachal Pradesh Krishi Vishwavidyalaya, Palampur, India
}

*Corresponding author: entomologist2018@gmail.com (ORCID ID: 0000-0001-8087-7934)

Paper No. 925

Received: 02-07-2021

Revised: 09-08-2021

Accepted: 09-09-2021

\begin{abstract}
Two years the random roving survey was conducted for occurrence and crop-wise distribution pattern of Entomopathogenic Nematode (EPN) in Solan and Sirmour districts of Himachal Pradesh under the Nematology Laboratory, Department of Entomology, Dr. Yashwant Singh Parmar University of Horticulture and Forestry, -173230, Himachal Pradesh, India, Sirmour during 2019-2020. Total 225 soil samples were collected from all Solan and Sirmaur districts, of which 68 samples were found EPN positive. The percent occurrence of Steinernema and Heterorhabditis was $27.03 \%$ and $27.45 \%$, respectively. The maximum frequency of occurrence (56\%) was recorded from Rajgarh and the minimum (12\%) from Halonipul, Sirmaur district. In the crop-wise distribution pattern, the maximum frequency was observed in fruit crops (80 \%) which was followed by plantation crops (35\%), ornamental crops (25\%).
\end{abstract}

\section{HIGHLIGHTS}

(0 Distribution of Entomopathogenic Nematodes in mid-hills of Himalyas.

o Morphological identification in the laboratory.

(0 Study of Frequency of occurrence of EPN from two districts of Himachal Pradesh. India.

( Entomopathogenic nematode distribution pattern in crop-wise.

Keywords: EPN, Survey, Steinernema, Heterorhbditis, Frequency, Horticulture Crops

Entomopathogenic nematodes (EPN) from Heterorhabditidae (Poinar 1976) and Steinernematidae (Travassos 1927) families are obligate insect parasites that can infect and kill a broad range of insect hosts (Kaya and Gaugler 1993). These nematodes are symbiotically associated with entomopathogenic bacteria Photorhabdus (Boemare et al. 1993) and Xenorhabdus (Thomas and Poinar 1979). These nematodes are currently marketed globally for the biological control of insect pests (Grewal et al. 1998).

Entomopathogenic nematodes (EPNs) belong to the genus Steinernema, and Heterorhabditis can control a diverse of insect pests due to their efficiency within a short period, compatibility with pesticides, and active host-seeking ability (Dowds and Peters 2002). They partially owe their pathogenicity to their symbiotic relationship with bacteria of the genus Xenorhabdus and Photorhabdus (Bedding et al. 1983; Forst et al. 1997; da Silva et al. 2000). Although there are some constraints for successful application of EPNs in the field, like environmental extremes or the resistance of certain pests to EPN penetration (Lewis et al. 2006; Georgis et al. 2006; Toepfer et al. 2010), they can be as effective as chemical

How to cite this article: Kasi, I.K., Singh, M., Waiba, K.M. and Monika 2021. Occurrence and Distribution of Entomopathogenic Nematodes in Horticultural Crops Soils of Solan and Sirmaur District of Himachal Pradesh, India. IJAEB, 14(03): 393-397.

Source of Support: None; Conflict of Interest: None 
insecticides under certain conditions (Laznik and Trdan 2017). Also, EPNs can be applied together with other agro-chemicals, time-saving, providing cost-effective and long-lasting pest control (Ozdemir et al. 2020a). For this purpose, many studies have been conducted with local EPN species and isolates, testing their pathogenicity on important pests and their compatibility with registered pesticides to design more sustainable pest control programs (Baimey et al. 2015; Ferreira et al. 2016; Hazir et al. 2018; Kwizera and Susurluk 2017; Laznik and Trdan 2014, 2017; Ogretmen et al. 2020; Ozdemir and Evlice 2020; Ozdemir et al. 2020b).

EPN belongs to the family; Heterorhabditidae and Steinemematidae are represented by the genera, Heterorhabditis Poinar and Steinernema Travassos and Neosteinernema Nguyen \& Smart, respectively. The state of Assam is hot with humid rich in a wide range of flora and fauna, and has a vast diversity of both beneficial and harmful insect pests. There has been no systematic survey for EPNs carried out in Himachal Pradesh till today. The current survey was the first conducted in Himachal Pradesh and specially focused on the Sirmaur district of Himachal Pradesh. The primary objectives of this study were to survey entomopathogenic nematodes from the families Heterorhabditidae and Steinernematidae in the Solan and Sirmaur districts of Himachal Pradesh to find out the distribution pattern of EPN, their ecosystem, and habitat.

\section{MATERIALS AND METHODS}

\section{Location and Area}

The district Solan and Sirmaur of Himachal Pradesh is hill zones of the Himalayas. The district comes under mid-hills. In the case of the vegetation structure of Solan, Sirmaur is concerned, the district comprises of broad types of horticulture land to forest areas. Localities where sampling for EPNs was conducted covering in the district (Table 1).

\section{Methods of collection}

A random traveling survey collected total 225 soil samples from all the two districts of Himachal Pradesh from June 2019 to November 2020, covering all cropped areas and horticulture crop habitats (Apple, Peach, Apricot, Plum, Persimmon... etc) (Fig. 1).

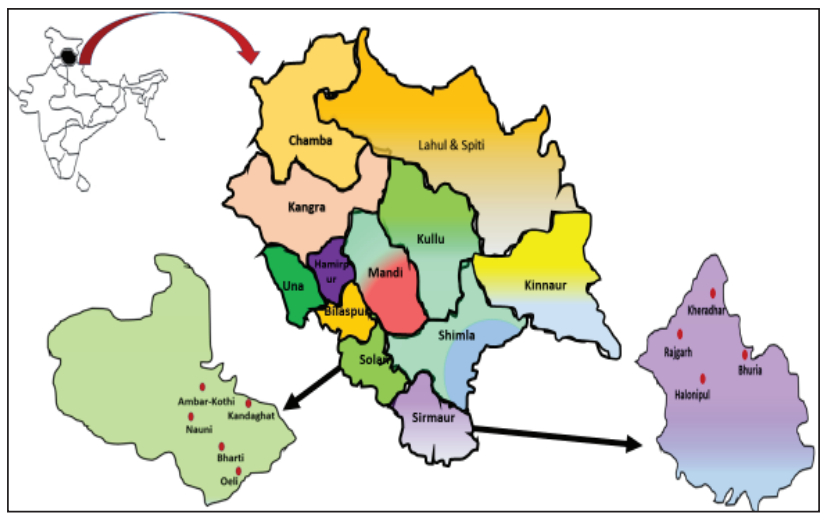

Fig. 1: Solan and Sirmaur district of Himachal Pradesh showing selected locations for survey work. (Source: QGIS)

Relatively more excellent, shady, and moist sites were chosen for soil sample collection. About 1000 $\mathrm{g}$ of soil was collected from each malty sampling site at a 10-15 cm depth from the soil surface. The EPNs were isolated from the soil samples by insect baiting technique using late instar larvae of G. mellonella (Bedding and Akhrust 1975). The initial culture was obtained from the Nematology Laboratory, Department of Entomology, Dr. YSP

Table 1: Localities where sampling for EPNs was conducted covering in the district of Solan and Sirmaur, Himachal Pradesh, India

\begin{tabular}{lllll}
\hline Districts & Localities & Latitude & Longitude & Altitude (m) \\
\hline Solan & Nauni & $30^{\circ} 51^{\prime} 33 \mathrm{~N}$ & $77^{\circ} 10^{\prime} 30 \mathrm{E}$ & 1179 \\
& Ambar-kothi & $30^{\circ} 51^{\prime} 07 \mathrm{~N}$ & $77^{\circ} 13^{\prime} 26 \mathrm{E}$ & 1300 \\
& Oeli & $30^{\circ} 51^{\prime} .02 \mathrm{~N}$ & $77^{\circ} 14^{\prime} 27 \mathrm{E}$ & 1350 \\
& Bharti & $30^{\circ} 59^{\prime} 45 \mathrm{~N}$ & $77^{\circ} 01^{\prime} 08 \mathrm{E}$ & 1150 \\
& Kanda ghat & $30^{\circ} 57^{\prime} 23 \mathrm{~N}$ & $77^{\circ} 06^{\prime} 49 \mathrm{E}$ & 1480 \\
\hline Sirmaur & Rajgarh & $30^{\circ} 53^{\prime} 15 \mathrm{~N}$ & $77^{\circ} 16^{\prime} 07 \mathrm{E}$ & 1682 \\
& Kheradhar & $30^{\circ} 08^{\prime} 24 \mathrm{~N}$ & $77^{\circ} 15^{\prime} 05 \mathrm{E}$ & 2032 \\
& Bhuira & $30^{\circ} 49^{\prime} 38 \mathrm{~N}$ & $77^{\circ} 20^{\prime} 07 \mathrm{E}$ & 1650 \\
& Halonipul & $30^{\circ} 51^{\prime} 03 \mathrm{~N}$ & $77^{\circ} 18^{\prime} 44 \mathrm{E}$ & 1349 \\
\hline
\end{tabular}


University of Horticulture and Forestry, Himachal Pradesh. After thoroughly mixing the soil sample a representative volume of soil (ca $250 \mathrm{~g}$ ) will be transferred to a plastic jar (ca $500 \mathrm{ml})(8 \mathrm{~cm}$ height and $6 \mathrm{~cm}$ diameter) containing 5-7 full-grown larvae of Galleria larvae. The jars were incubated at $25 \pm$ $1{ }^{\circ} \mathrm{C}$ temperature for 7 days. Every alternate day samples were observed for EPN infection. The larval cadavers, if any, were collected from the soil sample, washed with distilled water, and placed on White's trap (White, 1927) to observe the emergence of IJs. The collected nematode isolates were identified as EPNs after confirming their pathogenicity against the larvae of G. mellonella.

\section{Identification}

To identify EPN species, the isolated infective juveniles (IJs) were killed by gentle heating at $60^{\circ} \mathrm{C}$ in water and fixed in TAF $(7 \mathrm{ml}$ formalin $+2 \mathrm{ml}$ triethanolamine $+91 \mathrm{ml}$ distilled water). After keeping the nematodes in fixative for 5-7 days, they were transferred to a cavity block with ethanol, water, and glycerine in the ratio of 15: 5: 1 and kept in desiccators for 15 days. After that the IJs were mounted in glycerol on a glass slide. EPN species were identified with the help of published literature (Adam et al. 2006; Adams and Nguyen 2002; Hominick et al. 1997). Measurements were taken using a Leica IM50 microscope fitted with a light distortion difference. Some of the varieties have been identified and verified by comparisons with equipment from the Nematology Laboratory, in Dr. YSP UHF, Himachal Pradesh. India and the identified species were arranged in a systematic order.

\section{Statistical Analysis}

Microsoft Excel has been used to analyze morphometric variability in men and IJs. Data collected were analyzed using PASW 18 no the percent frequency of occurrence (F) of entomopathogenic nematode in different districts as well as crops were calculated using the following formula:

$$
\frac{(\text { EPN Positive samples })}{(\text { Total number of samples })} \times 100
$$

\section{RESULTS}

EPN were recovered from 68 samples out of 225 soil samples collected from two districts (Solan and Sirmaur) of Himachal Pradesh, and the frequency was recorded highest in Rajgarh $56 \%$, followed by $40 \%$ in Kheradhar Sirmaur district, $36 \%$ in Ambarkothi, and 32\% in Kanda ghatSolan district respectively. The frequency of occurrence in the region ranges from 56-12 percent. Among 68 positive samples, 44 samples $(27.03 \%)$ contained Steinernematid, and 24 contained Heterorhabditis. The highest recovery of EPN from Rajgarh of Sirmaur district is $56 \%$ is an indication of the suitable climate for the survival and multiplications of EPNs that prevail in the area (Table 2).

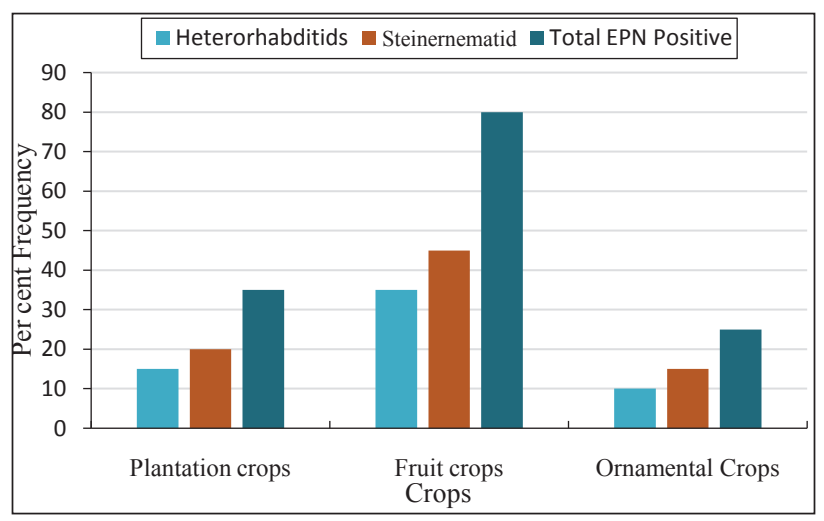

Fig. 2: Frequency of occurrence of EPN in different crops in Solan and Sirmaur district, Himachal Pradesh, India

The highest crop-wise distribution of EPN was recorded in fruit crops $(80 \%)$ followed by plantation crops (36\%) and ornamental crops (25\%) (Table 3 and Fig. 2).

\section{DISCUSSION}

The abundance of native EPNs was observed in the surveyed area (27 samples out of 120) may be due to prevailing ecosystems where human impact is substantial, like perennial orchards. This result conforms with Shahina et al. (1998). He reported that the abundance of native EPNs is high in an ecosystem with substantial human impact. Significant variations in the occurrence of EPNs can also be exacerbated by the combination of insecticides (Marcek and Becvar 2000). The region has fertile, compacted sandy loam with a good vegetative cover. In addition to the normal rainfall in Himachal Pradesh, these conditions should have 
Table 2: Frequency of occurrence of EPN from two districts of Himachal Pradesh, India

\begin{tabular}{llllll}
\hline Districts & $\begin{array}{l}\text { Name of the } \\
\text { location }\end{array}$ & $\begin{array}{l}\text { Altitude } \\
(\mathbf{m})\end{array}$ & $\begin{array}{l}\text { Total no of sample } \\
\text { collected }\end{array}$ & $\begin{array}{l}\text { No of sample } \\
\text { with EPN }\end{array}$ & $\begin{array}{l}\text { Frequency of } \\
\text { occurrence (\%) }\end{array}$ \\
\hline Solan & Nauni & 1179 & 25 & 5 & 25 \\
& Ambarkothi & 1300 & 25 & 9 & 36 \\
& Oeli & 1350 & 25 & 7 & 28 \\
& Bharti & 1150 & 25 & 5 & 20 \\
& Kanda ghat & 1480 & 25 & 8 & 32 \\
\hline Sirmaur & Rajgarh & 1682 & 25 & 14 & 56 \\
& Kheradhar & 2032 & 25 & 10 & 40 \\
& Bhuira & 1650 & 25 & 7 & 28 \\
& Halonipul & 1349 & 25 & 3 & 12 \\
\hline
\end{tabular}

Table 3: Crop wise distribution pattern of EPN in the district of Solan and Sirmaur, Himachal Pradesh, India

\begin{tabular}{llllll}
\hline \multirow{2}{*}{ Crops } & Heterorhabdities & Steinernematid & $\begin{array}{l}\text { Frequency of } \\
\text { EPN Positive } \\
\text { (\%) }\end{array}$ \\
\cline { 2 - 6 } & $\begin{array}{l}\text { Number/20 } \\
\text { sample }\end{array}$ & Frequency (\%) & $\begin{array}{l}\text { Number/20 } \\
\text { sample }\end{array}$ & Frequency (\%) \\
\hline Plantation crops & 3 & 15 & 4 & 20 & 35 \\
Fruit crops & 7 & 35 & 9 & 45 & 80 \\
Ornamental Crops & 2 & 10 & 3 & 15 & 25 \\
\hline
\end{tabular}

supported the survival and proliferation of host pests and ultimately the high emergence of EPNs, especially in fruit plants due to the shade and high humidity under a large tree bed.

\section{CONCLUSION}

The surveys have shown that all five blocks of districts are rich in EPN diversity and Steinernematids and Heterorhabditids in fruit crops, plantation crops, ornamental crops, and field crops of the district indicates their potential role in the natural control of soil-inhabiting insect pests of major crops. The study has also necessitated further study on taxonomic and molecular characterization and host ranges of these EPN species to explore and ascertain their possible potential scope to use as a biological control agent.

\section{REFERENCES}

Adams, B.J., Fodor, A., Koppenhofer, H.S., Stackebrandt, E., Stock, S.P. and Klein, M.G. 2006. Biodiversity and systematics of nematode bacterium entomopathogens. Biol Control, 37: 32-49.

Baimey, H., Zadji, L., Afouda, L., Moens, M. and Decraemer, W. 2015. Influence of pesticides, soil temperature and moisture on entomopathogenic nematodes from southern Benin and control of underground termite nest populations. Nematology, 17(9): 1057-1069.
Bedding, R.A. and Akhrust, R.J. 1975. A simple technique for the detection of insect parasitic rhabditid nematodes in soil. Nematologica, 21: 109-110.

Bedding, R.A., Molyneux, A.S. and Akhurst, R.J. 1983. Heterorhabditis spp., Neoaplectana spp., and Steinernema kraussei: interspecific and intraspecific differences in infectivity for insects. Exp. Parasitol., 55: 249-257.

Boemare, N.E., Akhurst, R.J. and Mourant, R.G. 1993. DNA relatedness between Xenorhabdus spp.(Enterobacteriaceae), symbiotic bacteria of entomopathogenic nematodes and a proposal to transfer Xenorhabdus luminescens to a new genus, Photorhabdusgen. nov. Int. J. Syst. Bacteriol., 43: 249-255.

da Silva, C.C.A., Dunphy, G.B. and Rau, M.E. 2000. Interaction of Xenorhabdus nematophilus (Enterobacteriaceae) with the antimicrobial defenses of the house cricket, Acheta domestica. J. Invertebr. Pathol., 76: 285-292.

Dowds, B.C.A. and Peters, A. 2002. Virulence mechanisms. In: Gaugler, R. (Ed.), Entomopathogenic Nematology. NY: CABI, New York, pp. 79-98.

Ferreira, T., Van Reenen, C.A., Tailliez, P., Pages, S., Malan, A.P. and Dicks, L.M.T. 2016. First report of the symbiotic bacterium Xenorhabdus indica associated with the entomopathogenic nematode Steinernema yirgalemense. J. Helminthol, 90(1): 108.

Forst, S., Dowds, B., Boemare, N. and Stackebrandt, E. 1997. Xenorhabdus and Photorhabdus spp.: bugs that kill bugs. Annu. Rev. Microbiol., 51: 47-72.

Georgis, R., Koppenhofer, A.M., Lacey, L.A., Belair, G., Duncan, L.W. and Grewal, P.S. 2006. Successes and failures in the use of parasitic nematodes for pest control. Biol. Contr., 38: 103-123. 
Grewal, P.S. and Georgis, R. 1998. Entomopathogenic nematodes, Methods in Biotechnology. Biopest., 5: 271-299.

Hazir, S., Shapiro-Ilan, D.I., Bock, C.H. and Leite, L.G. 2018. Thermo-stability, dose effects and shelf-life of antifungal metabolite-containing supernatants produced by Xenorhabdus szentirmaii. Eur. J. Plant Pathol., 150(2): 297-306.

Hominick, W.M., Briscoe, B.R., del Pino, F.G., Heng, J.A., Hunt, D.J., Kozodoy, E., Mracek, Z., Nguyen, K.B., Reid, A.P. and Spiridonov, S. 1997. Biosystematics of entomopathogenic nematodes: current status, protocols and definitions. J. Helminthol., 71: 271-298.

Kaya, H.K. and Gaugler, R. 1993. Entomopathogenic nematodes. Annual Rev. Entomol., 38: 181-206.

Kwizera, V. and Susurluk, I.A. 2017. Evaluation of the effects of some insecticides based on neonicotinoids on entomopathogenic nematodes, Steinernema feltiae and $S$. carpocapsae, Isj-Invertebr. Survive J., 14: 375-378.

Laznik, Z. and Trdan, S. 2014. The influence of insecticides on the viability of entomopathogenic nematodes (Rhabditida: Steinernematidae and Heterorhabditidae) under laboratory conditions. Pest Manag. Sci., 70(5): 784-789.

Laznik, Z. and Trdan, S. 2017. The influence of herbicides on the viability of entomopathogenic nematodes (Rhabditida: Steinernematidae and Heterorhabditidae). Int. J. Pest Manag., 63(2): 105-111.

Lewis, E.E., Campbell, J., Griffin, C., Kaya, H. and Peters, A. 2006. Behavioral ecology of entomopathogenic nematodes. Biol. Contr., 38(1): 66-79.

Mracek, Z., Becvar, S. and Kindlmann, P. 2000. Survey of entomopathogenic nematodes from the families Steinernematidae and Heterorhabditidae (Nematoda: Rhabditida) in Czech Republic. Folia Parasitologica, 46: 145-148.

Ogretmen, A., Yuksel, E. and Canhilal, R. 2020. Susceptibility of larvae of wireworms (Agriotes spp.) (Coleoptera: elateridae) to some Turkish isolates of entomopathogenic nematodes in the laboratory and field conditions. Biol. Contr., 104320.
Ozdemir, E., Bayram, S. and Susurluk, I.A. 2020b. First record of the entomopathogenic nematode Steinernema litorale (Filipjev)(Rhabditida: Steinernematidae) and its symbiotic bacterium from Turkey, and its efficacy capability. Insects, 11(3): 144.

Ozdemir, E., Inak, E., Evlice, E. and Laznik, Z. 2020a. Compatibility of entomopathogenic nematodes with pesticides registered in vegetable crops under laboratory conditions. J. Plant Dis. Prot., 127: 529-535.

Poinar, G.O. 1976. Description and biology of a new insect parasitic rhabditoid, Heterorhabditis bacteriophora n. gen. n. sp. (Rhabditida: Heterorhabditidae n. fam.). Nematologica., 21: 463-470.

Shahina, F., Anis, M., Zainab, S. and Maqbool, M.A. 1998. Entomopathogenic nematodes in soil samples collected from Sindh, Pakistan. Pakistan J. Nematology, 16: 41-50.

Thomas, G.M. and Poinar, J.G.O. 1979. Xenorhabdus gen. nov. a genus of entomopathogenic, nematophilic bacteria of the family Enterobacteriaceae. Int. J. Syst. Bacteriol., 29: 352-360.

Toepfer, S., Kurtz, B. and Kuhlmann, U. 2010. Influence of soil on the efficacy of entomopathogenic nematodes in reducing Diabrotica virgifera in maize. J. Pest. Sci., 83: 257-264.

Travassor, L. 1927. Sobre O genera oxysomatum. Bol. Biol. Sea Paolo., 5: 20-21.

White, G.F. 1927. A method for obtaining infecting nematode larvae from cultures. Sci., 66: 302-303.

Zdemir, E. and Evlice, E. 2020. Assessment of the susceptibility of the Turkestan cockroach, Blatta lateralis to Turkish isolates of entomopathogenic nematodes. Turk. J. Biol. Control, 11(1): 127-139. 
